UDC [УДК] 629.438.4

DOI 10.17816/transsyst20184252-61

(C) V. A. Bogachev ${ }^{1}$, Y. A. Terentyev ${ }^{2}$, V. V. Koledov ${ }^{3}$, T. V. Bogachev ${ }^{4}$

${ }^{1}$ Rostov State Transport University (RSTU)

(Rostov-on-Don, Russia)

${ }^{2}$ Independent expert, official representative of ET3 in the Russian Federation (Moscow, Russia)

${ }^{3}$ Insitite of Radioengineering and Electronics of RAS (Kotelnikov IRE RAS)

(Moscow, Russia)

${ }^{4}$ Rostov State University of Economics

(Rostov-on-Don, Russia)

\title{
DZUNGARIA CORRIDOR FOR VACUUM MAGNETIC LEVITATION TRANSPORT: LOST OPPORTUNITIES OR WEIGHTED OPTIMISM?
}

Background: The complex of issues arising when considering possible options for the implementation of Eurasian transcontinental high-speed land transport corridors operating on the basis of vacuum magnetic-levitation technologies is analyzed. The exclusivity of Russia's geographical position in a substantial part lies in the fact that it is through its territory that China can be directly linked by these corridors to Western Europe and also to North America, the rationale is done.

Aim: Possible routes connecting Beijing and Shanghai with Moscow are analyzed. Transport highways of a truly innovative type will solve the urgent task of geopolitical level to organize the states located on the Eurasian continent in a qualitatively new civilizational construction. The purpose of the research is as follows: to develop methods of solving the problems of finding optimal variants for the location of high-speed land transport corridors using computer mathematics systems. This should take into account the features of the territory, through which the transport route is planned to be carried out.

Methods: The economic, political, logistical, geographical, technical and technological aspects of these projects are discussed. Optimization methods are used, in particular, the calculus of variations.

Results: After the creation of a sufficiently informative and detailed informal picture, the basics of the corresponding mathematical models are constructed.

Conclusion: The historical area of Dzungaria is considered as the location of the main intermediate terminal for high speed vacuum magnetic levitation transport.

Keywords: High-speed land transport corridors, Magnetic-levitation technologies, Optimization methods, The problem of the calculus of variations.

The research is conducted with a support of the Russian Foundation for Basic Research (Grant No. 17-20-04236 офи_м_РЖД) 
() В. А. Богачев ${ }^{1}$, Ю. А. Терентьев ${ }^{2}$, В. В. Коледов ${ }^{3}$, Т. В. Богачев ${ }^{4}$

${ }^{1}$ Ростовский государственный университет путей сообщения (РГУПС) (г. Ростов-на-Дону, Россия)

${ }^{2}$ Независимый научный эксперт, официальный представитель «ВТ3» в

России (г. Москва, Россия)

${ }^{3}$ Институт радиотехники и электроники РАН

(г. Москва, Россия)

${ }^{4}$ Ростовский государственный экономический университет

(г. Ростов-на-Дону, Россия)

\section{ДЖУНГАРСКИЙ КОРИДОР ДЛЯ ВАКУУМНОГО МАГНИТОЛЕВИТАЦОННОГО ТРАНСПОРТА: УПУЩЕННЫЕ ВОЗМОЖНОСТИ ИЛИ РАЗУМНЫЙ ОПТИМИЗМ?}

Обоснование: Анализируется комплекс вопросов, возникающих в процессе рассмотрения возможных вариантов реализации евразийских трансконтинентальных высокоскоростных наземных транспортных коридоров на основе технологий вакуумной магнитной левитации. В работе выполнено обоснование, согласно которому, исключительность географического положения России в значительной степени заключается в том, что именно через ее территорию Китай может быть напрямую связан подобными коридорами со странами Западной Европы, а также с Северной Америкой.

Цель: Анализируются возможные маршруты, соединяющие Пекин и Шанхай с Москвой. Транспортные магистрали действительно инновационного характера решат важную задачу геополитического масштаба, а именно: организовать государства Евразии согласно качественно новому цивилизационному укладу. Цель исследования заключается в следующем: разработать методы решения задач по поиску оптимальных вариантов местоположения высокоскоростных наземных транспортных коридоров с применением компьютерных математических систем. Следует учитывать и особенности территории, по которой планируется проложить данную транспортную линию.

Методы: Обсуждаются экономические, политические, логистические, географические, технико-технологические аспекты реализации данных проектов. Использованы методы оптимизации, в частности, вариационное исчисление.

Результаты: После получения в достаточной степени информативной и подробной картины созданы соответствующие базовые математические модели.

Вывод: Историческая область Джунгария рассматривается в качестве основного промежуточного терминала для высокоскоростного вакуумного магнитолевитационного транспорта.

Ключевые слова: Высокоскоростные наземные транспортные коридоры, технологии магнитной левитации, методы оптимизации, проблема вариационного исчисления.

Исследование проведено при поддержке Российского фонда фундаментальных исследований (Грант №. 17-20-04236 офи_м_РЖД). 


\section{INTRODUCTION}

In this paper, we analyze a number of issues that arise when considering possible options for the implementation of trans-Eurasian high-speed ground corridors operating on the basis of vacuum magnetic levitation transport (VMLT). A very extensive literature is devoted to a discussion of the comprehensive aspects of the application of magnetic levitation technologies in transport, including in vacuum tubes, from a wide variety of points of view [1-18]. Note that the conclusions made after a very versatile and detailed analysis of the expediency of using these technologies at the present time often turn out to be contradictive (it suffices to compare $[2,3,4,7,10]$ ).

The purpose of the present research is to develop mathematical methods of solving the problems of finding optimal variants for the location of highspeed land transport corridors using computer mathematics systems. This should take into account the characteristic features of the territory, through which the transport route is planned to be carried out.

\section{SOME NATIONAL ASPECTS OF VMLT PROJECTS FOR THE RUSSIAN FEDERATION}

Exclusiveness of the geographical position of Russia is expressed not only by the record area of the territory and by the fact that it is in two parts of the world. In modern geo-economic and geopolitical conditions, this exclusiveness is due to the fact that it is through Russia that China can be directly connected by high-speed land transport corridors with Western Europe and also with North America.

The relief of Central Asia that was rich in mountain systems served as a natural reason for the isolation of the Celestial Empire (which also provokes its artificial self-isolation) and, in general, the states of East Asia from Europe and even from Middle East until the end of the 19th century. The modern China, which is carrying out omnidirectional and all-pervasive expansion, not only makes up for the time-lost isolation from the Western world, supplemented by three decades of "classical" socialism. It is already clear to all that its goal is to become even more powerful in "multipolar" World.

By boosting its nomination for world leadership positions in economic, scientific, technical, technological and even to some extent social relations, Chine is building up the "muscular relief of the whole body" externally positioning itself at the same time not aggressively. It is clear that with such actively developing global market relations, further full-fledged progress is simply not possible without the transcontinental transport highways of a fundamentally new, real innovative type. As for such geographical neighbors of Russia and China as Kazakhstan, Uzbekistan, Turkmenistan, Kyrgyzstan and 
Tajikistan, we note the following. It is known that from 1992 to 2012, China's aggregate trade with these five Central Asian countries increased 100-fold and increased to 46 billion dollars. Thus, one can't doubt their direct and even vital interest in the implementation of the projects of innovative high speed transportation under consideration.

\section{DZUNGARIA CORRIDOR AS A PILOT PROJECT IN IMPLEMENTATION OF VMLT}

When choosing trajectory for high speed overland route between Beijing and Moscow or Shanghai and Moscow operating on the basis of VMLT, the physical map of Central Asia immediately identifies Dzungaria, a historical region located in the Xinjiang Uygur Autonomous Region of China. As noted above, the geographic complexity of the situation is that across any of the possible routes connecting East China to Europe, one way or another, there is an extended chain of mountain systems passing one another. However, it is in Dzungaria that there are fairly wide and relatively flat passages in this chain. The most famous is called "Dzungarian Gate". We draw attention to another, less known passage located $150 \mathrm{~km}$ to the north of the "Dzungarian Gate".

So, let's consider from the geographical, political, economic and social point of view one of the possible nearly "rectilinear" routes connecting Beijing and Moscow. The movement from Beijing will take place all the time to the north-west-west. After crossing the Gobi Desert in a very insignificant extreme southern part of the territory of Mongolia, the Gobi Altai and the Mongolian Altai remain to the north of the route. The movement will again take place across the territory of China to its border with Kazakhstan. Here between the ridges of Dzungarian Alatau and Tarbagatai there is a flat passage, which we will call the "New Dzungar Gate". From the south of the route, there will be Lake Manas (Ike-Khan) and the city of Karamay. From the north - the city of Durbuljin (Emin) and Chuguchak (Tacheng). After crossing the border of China with Kazakhstan, the cities of Bakhta and Urjar will remain from the north. Further movement occurs practically along the plain. Leaving from the south of Lake Alakol and Balkhash and from the north - the top of $1565 \mathrm{~m}$, and then from the south - Mount Ulytau (1133 m), located in the Kazakh, the route goes to the Southern Urals. The largest cities of Kazakhstan: Karaganda and Astana will remain located north of the route, respectively, at $150 \mathrm{~km}$ and $300 \mathrm{~km}$. After crossing the border of Kazakhstan with Russia, the route enters the Orenburg region of Russia.

Let's sum up some results. The length of the entire route from Beijing to Moscow will be about $6150 \mathrm{~km}$. The time of delivery of passengers and cargo will be close to the minimum in comparison with all other routes. From the point of view of the minimum material costs for surveying and construction 
work, this route is also preferable to others. Indeed, the mountain ranges are left out, and the second half of the route passes almost across the flat terrain. In any case, for many well-understood reasons, somewhat north of the city of Urumqi, the center of the Xinjiang Uygur Autonomous Region, the main intermediate terminal should be located, which will serve as a powerful hotbed of economic and social development for the entire western part of China.

\section{VARIATION APPROACH IN MATHEMATICAL MODELING OF TRANSPORT AND LOGISTIC CONSTRUCTINGS}

When considering possible variants of the location of transport highways, immediately questions arise relating to their curvature. Even for traditional railroads constructed on the basis of the "wheel-rail" system, their curvature is the most important indicator determining the permissible speed of trains. For high-speed, and even more ultra-high-speed railroads, the value of this indicator becomes dominant.

For the transport-logistical constructions performed in this work, the general variation method for solving the corresponding optimization problems is proposed.

When considering possible options for the location of railways, questions immediately arise concerning their curvature. Even for traditional railway tracks built on the basis of the "wheel-rail" system, their curvature is the most important indicator determining the permissible speed of trains.

Consider a capsule levitating in an evacuated tube by means of electromagnetic field forces and performing the function of a passenger or freight vehicle. The trajectory of the movement of the capsule is a certain line located on the ellipsoid surface of the Earth. The retention of the capsule on the trajectory should be provided by the centripetal force, which is the resultant force of gravity and the forces of the electromagnetic field and equal

$$
F(x, y, z)=\frac{m v^{2}}{R(x, y, z)} .
$$

Here $m$ - the weight of the capsule, $v=v(x, y, z)$ - the speed of its movement at the point of the line $\Gamma$ with the coordinates $x, y$ and $z$ (in some selected rectangular Cartesian coordinate system), $R(x, y, z)$ - the radius of curvature of the line $\Gamma$ at this point. As is known, the radius of curvature $k(x, y, z)$ of a line is expressed in terms of its curvature by equality $R(x, y, z)=\frac{1}{k(x, y, z)}$. 
In the "ideally-extreme" case for VMLT the line $\Gamma$ represents the line of intersection of a common terrestrial ellipsoid with a plane passing through three points, two of which are the ends of the route and the third is the center of the Earth. If, at the same time, the velocity of the capsule turns out to be equal to the first space flight it will be held in the indicated "orbit" by gravity only being together with the cargo or passengers in weightlessness.

The formula (1) shows that in view of the planned supersonic and even "space" speeds of levitating capsules, one of the main initial criteria when considering the variants of the highways is their curvature.

Let us proceed to the presentation of the proposed variational method. We will consider an optimization problem of the form:

$$
\min _{(x, y, z) \in \Gamma} R(x, y, z) \rightarrow \max
$$

or equivalent

$$
\max _{(x, y, z) \in \Gamma} k(x, y, z) \rightarrow \min
$$

provided that the location of the lines are subject to some restrictions. In the situation considered in this paper these restrictions are dictated by the terrain on which it is planned to lay the transport backbone.

Before the method of solving the optimization problem, we make the following General geometric remark. It is known that among all lines connecting any two given points, the smallest length has a line segment. At the same time, the curvature of the straight line is zero at all points.

To the problem under consideration this simple observation is relevant for the following reason. The point is that finding a line having the smallest length among the points connecting two data points and satisfying certain given conditions is, from the computational point of view a simpler task (since it requires fewer resources) than finding among those lines the one with the greatest curvature function of points of a line) is the smallest. However, the above coincidence for a straight line does not allow far-reaching generalizations. The corresponding counterexample is shown in Fig.1.

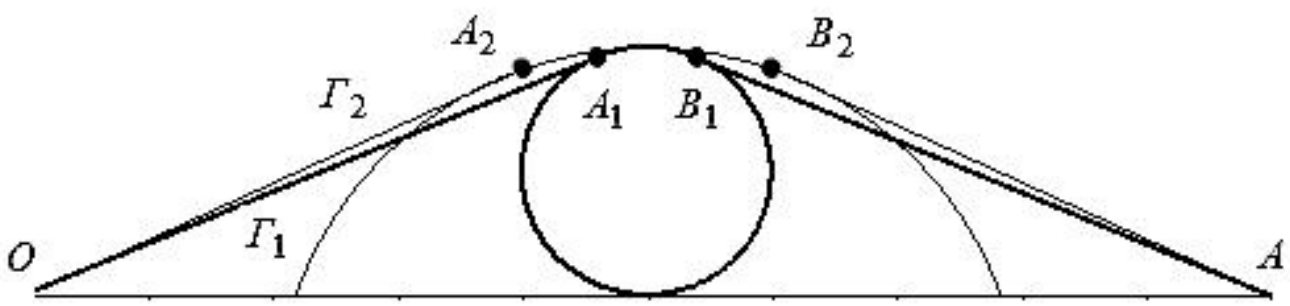

Fig.1. Lines $\Gamma_{1}$ and $\Gamma_{2}$

Let't give an explanation. The greatest value of a curvature of a line $\Gamma_{1}$ joining two fixed points $O$ and $A$ and not passing through the interior of a circle whose radius is assumed to be equal 1 is attained at each point of the arc 
$A_{l} B_{1}$ of this circle and is equal to $k_{l}=1$. The greatest value of the curvature of the line $\Gamma_{2}$, (also connecting points $O$ and $A$ and not passing through the interior of this circle) is reached at each point of the arc $A_{2} B_{2}$ of the circle of radius 2 and is equal to $k_{2}=\frac{1}{2}$. However, the length of the curve $\Gamma_{1}$ is less than the length of the curve $\Gamma_{2}$.

We also note that in the railway practice, for the coupling of the rectilinear part of the railway with the circular one, transitional curves are constructed to compensate for the resulting jump in the curvature of the path [19]. It is also not difficult to cite a counterexample taking this remark into account. In this case, for each of the more complex lines $\Gamma_{1}$ and $\Gamma_{2}$ the curvature will change continuously, but (as in the example above) the length $\Gamma_{1}$ is less than the length $\Gamma_{2}$.

We now turn our attention to the fact that Lagrange or Newton polynomials are used in the interpolational constructions performed below in the process of optimization. Therefore, the curvature of the lines $\Gamma$ received is a continuous (and even smooth) function.

Turn to the exposition of the algorithm for constructing a mathematical model in the environment of a computer mathematics system. For brevity and clarity, we confine ourselves to a two-dimensional case. Variation of the lines $\Gamma$ whose ends are assumed to be at fixed points $O$ and $A$ of the abscissa axis (Fig. 2) will be performed in such a way that the appropriate terrain is taken into account. Namely, the lines $\Gamma$ must bypass the soles of the mountains and the elevations located between the points $O$ and $A$.

The segment $O A$ is divided into $n$ equal parts by points $x_{i}$. The corresponding ordinates $y_{i}$ of the points of the plane can be found by a simple search, and using the randomization capabilities of the computer mathematics system. The main content of the constructions produced here is the choice of gaps in which the ordinates $y_{i}$ can be changed. At the same time, the specificity of the terrain is taken into account (in Fig. 2 this relief is indicated by shaded parts of circles and ellipses).

The interpolation polynomial $y(x)$ (for example, of the above type) is built for the obtained points $\left(x_{i}, y_{i}\right)$ of the plane. In principle, the use of splines is not excluded, although there are questions about the smoothness of value is found, that is, the maximum of the function $|k(x)|=\frac{\left|y_{x^{2}}^{\prime \prime}\right|}{\left(1+y_{x}^{\prime 2}\right)^{\frac{3}{2}}}$. 
The computational process ends with minimizing the indicated maxima and thereby finding the desired line.

In Fig. 2 shows a line $\Gamma$ that is a graphical result of the computer mathematics solution of an optimization problem with a terrain relief depicted in the form of shaded parts of circles and ellipses. In this case, the random number generator and the interpolation polynomials of Lagrange and Newton were used.

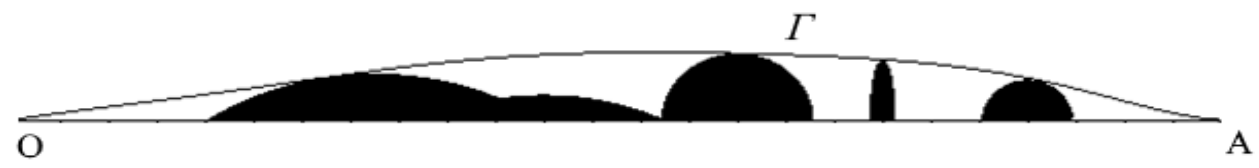

Fig. 2. The line found by the computer mathematics system

\section{CONCLUSION}

We formulate the results of the paper.

1) A general variational method for solving optimization problems using analytical computing systems has been developed, which makes it possible to carry out transport and logistics studies to find the optimal options for the location of high-speed land transport corridors.

2) Based on the proposed method, calculations are performed through the system of analytical calculations, the result of which is the optimal route for the location of the transport corridor, given the restrictions on the terrain, characterized by the presence of mountain chains and elevations.

\section{References}

1. Магнитолевитационная транспортная технология / Под ред. В. А. Гапановича. - М.: Физматлит, 2014. 476 c. [Gapanovich VA, editor. Magnitolevitacionnaya transportnaya tekhnologiya. Moscow: Fizmatlit; 2014. 476 p. (In Russ.)].

2. Магнитолевитационный транспорт: научные проблемы и технические решения / Под ред. Ю.Ф. Антонова, А.А. Зайцева. - М.: Физматлит, 2015. - 612 c. [Antonov YuF, Zaitsev AA, editors. Magnitolevitatsionnyi transport: nauchnye problemy i tekhnicheskie resheniya. Moscow: Fizmatlit; 2015. 612 p. (In Russ.)].

3. Зайцев А.А., Морозова Е.И., Талашкин Г.Н., Соколова Я.В. Магнитолевитационный транспорт в единой транспортной системе страны: Монография. - СПб: НП-Принт, 2015. - 140 с. [Zaitsev AA, Morozova EI, Talashkin GN, Sokolova YaV. Magnitolevitatsionnyi transport v edinoi transportnoi sisteme strany. St. Petersburg: NP-Print; 2015. 140 p. (In Russ.)].

4. Зайцев А.А. Отечественная транспортная система на основе магнитной левитации // Бюллетень Объединенного ученого совета ОАО «РЖД». - 2015. - № 6. - C. 22-27. [Zaitsev AA, Otechestvennaya transportnaya sistema na osnove magnitnoi levitatsii. Byulleten' Ob"edinennogo uchenogo soveta OAO "RZhD". 2015;6:22-27 (In Russ.)]. 
5. Technical-economical comparison of Maglev and High Speed Systems. Available at: http://archives-republicans-transportation.house.gov/ Media/ File/110th/Rail/320-07-roundtable-Brady-dornier.pdf. Accessed September 15, 2016.

6. The website of the Evacuated Tube Transport Technology. Available at: http://et3 .com/. Accessed October 25, 2016.

7. Терентьев Ю.А., Дроздов Б.В. Перспективы вакуумного магнитолевитационного транспорта // Мир транспорта. - 2017. - №1. - C. 90-95. [Terentiev YA, Drozdov BV. Prospects for Vacuum MagneticLevitation Transport. World of Transport and Transportation. 2017;1:90-95. (In Russ.)].

8. Островская Г. В. Магнитные дороги профессора Вейнберга (К 100-летию лекции «Движение без трения») // Вестник науки Сибири. - 2014. - № 2. - C. 6-16. [Ostrovskaya GV. Magnetic railways of professor Veinberg (Centennial of the lecture «Friction-free motion»). Siberian Journal of Science. 2014;2:6-14. (In Russ.)].

9. Дроздов Б.В. Геостратегические проекты дальневосточного развития России // Культура. Народ. Экосфера: труды социокультурного семинара имени Бугровского. - Вып. 4. - М.: Спутник+, 2009. Режим доступа: https://refdb.ru/look/1972048-pall.html. Дата обращения: 15.09.2016. [Drozdov BV. Geostrategicheskie proekty dal'nevostochnogo razvitiya Rossii. Kul'tura. Narod. Ekosfera: trudy sotsiokul'turnogo seminara imeni Bugrovskogo. Available from: https://refdb.ru/look/1972048-pall.html. Accessed September 15, 2016 (In Russ.)].

10. Фиронов А.Н. Вакуумно-левитационный транспорт: перспектива или тупик? // Транспорт Российской Федерации. Журнал о науке, экономике, практике. - 2017. - № 3(70). - C. 44-47. [Fironov AN. Vacuum-levitation transport: any potential or standing no chance? Transport of the Russian Federation. A magazine of science, economy and practice. 2017;3(70):44-48. (In Russ.)].

11. Yamamura S. Magnetic levitation technology of tracked vehicles present status and prospects. IEEE Transactions on Magnetics. 1976;12(6):874-878. doi: 10.1109/tmag.1976.1059125

12. Cai Y., Chen SS. Dynamic characteristics of magnetically levitated vehicle systems. Applied Mechanics Reviews, ASME. 1997;50(11):647-670. doi: 10.1115/1.3101676

13. Meins J., Miller L., Mayer W.J. The high speed maglev transportation system transrapid. IEEE Transactions on Magnetics. 1998;24(2):808-811. doi: $10.1109 / 20.11347$

14. Luguang Y. Progress of the maglev transportation in China. IEEE Trans Appled Superconductivity. 2006;16(2):1138-1141. doi: 10.1109/tasc.2006.871345

15. Lee KW, Kim KC, Lee J. Review of maglev train technologies. IEEE Transactions on Magnetics. 2006;42(7):1917-1925. doi: 10.1109/tmag.2006.875842

16. Zhang Y., Oster D., Kumada M., et al. Key vacuum technology issues to be solved in evacuated tube transportation. Journal of Modern Transportation. 2011;19(2):110-113. doi: 10.1007/bf03325748

17. Han H-S, Kim D-S. Magnetic Levitation Maglev Technology and Applications. Springer Science+Business Media, Dordrecht; 2016. 247 p. doi: 10.1007/978-94017-7524-3_6

18. Винокуров В.А., Галенко А.А., Горелов А.Т. и др. Транспортные системы с магнитным подвешиванием и линейным электроприводом. Энциклопедия, в 
40 т. - М.: Изд-во Машиностроение, 2008. - 656 с. [Vinokurov VA, Galenko AA, Gorelov AT et al. Transportnye sistemy s magnitnym podveshivaniem i lineinym elektroprivodom. Moscow: Izdatel'stvo Mashinostroenie; 2008. 656 p. (In Russ.)].

19. Фихтенгольц Г.М. Курс дифференциального и интегрального исчисления. М.: Изд-во Наука, 1969. - T. 1. - 607 с. [Fikhtengol'ts GM. Kurs differentsial'nogo i integral'nogo ischisleniya. Moscow: Izdatel'stvo Nauka; 1969, vol. 1.607 p. (In Russ.)].

\section{Information about the authors:}

Viktor A. Bogachev, PhD in Physico-mathematical sciences

Adress: 344038, Rostov-on-Don, Russia, st. Lenina 44/2-4

eLibrary SPIN:2125-5198; ORCID: 0000-0003-1202-7318;

E-mail: bogachev-va@yandex.ru

Yuri A. Terentyev

ORCID: 0000-0002-0888-9057;

E-mail: teren_y@mail.ru

Victor V. Koledov, Doctor of Physico-mathematical sciences

eLibrary SPIN: 9291-1989; ORCID: 0000-0002-2439-6391;

E-mail: victor_koledov@mail.ru

Taras V. Bogachev, PhD in Physico-mathematical sciences eLibrary SPIN:2262-0080; ORCID: 0000-0001-9641-0116;

E-mail: bogachev73@yandex.ru

\section{Сведения об авторах:}

Богачев Виктор Алексеевич, к.ф.-М. Н., доцент

Адрес: 344038, Ростов-на-Дону, пр. Ленина 44/2-4.

eLibrary SPIN:2125-5198; ORCID: 0000-0003-1202-7318;

E-mail: bogachev-va@yandex.ru

Терентьев Юрий Алексеевич

ORCID: 0000-0002-0888-9057;

E-mail: teren_y@mail.ru

Коледов Виктор Викторович, д.ф.-м.н., с.н.с.

eLibrary SPIN: 9291-1989; ORCID: 0000-0002-2439-6391;

E-mail: victor_koledov@mail.ru

Богачев Тарас Викторович, к.ф.-м. н., доцент

eLibrary SPIN:2262-0080; ORCID: 0000-0001-9641-0116;

E-mail: bogachev73@yandex.ru

\section{To cite this article:}

Bogachev VA, Terentyev YA, Koledov VV, Bogachev TV. Dzungaria Corridor for Vacuum Magnetic Levitation Transport: Lost Opportunities or Weighted Optimism? Transportation Systems and Technology. 2018;4(2):52-61. doi: 10.17816/transsyst20184252-61

\section{Цитировать:}

Богачев В.А., Терентьев Ю.А.,Коледов В.В., Богачев Т.В. Джунгарский коридор для вакуумного магнитного левитационного транспорта: утерянные возможности или взвешенный оптимизм? // Транспортные системы и технологии. - 2018. - Т. 4. - № 2. - C. 52-61. doi: 10.17816/transsyst20184252-61 